\title{
Rise and Fall of Kema Port in Sulawesi Sea Trade Routes During Colonial Period: Based on Infrastructure Data
}

\author{
Irfanuddin Wahid Marzuki \\ Balai Arkeologi Yogyakarta \\ J1. Gedongkuning No. 174, Yogyakarta 55171, Indonesia \\ irfanudin.wahid@kemdikbud.go.id
}

Received: 29/01/2018; revisions: 06/03 - 14/05/2018; accepted: 03/06/2018

Published online: 31/07/2018

\begin{abstract}
Kema is one of the districts in Minahasa Utara Regency located on the southern coast of Sulawesi Utara. Currently, Kema is known as a densely populated fishing village which is divided into Kema Satu, Kema Dua, and Kema Tiga. Based on historical data, Kema has been known since the 16 century by European sailors who stopped to fill drinking water, then expanded into a port city. This study aims to determine the rise and fall of the existence of Kema in the global trade of the Sulawesi Sea in the colonial period based on archaeological and historical data. This study uses a historical archeology approach that combines archaeological data with historical data. Research stages include data collection phase, data analysis, and conclusion. The results indicate archaeological evidence shows that Kema was an advanced settlement, covering the settlement patterns and road networks, ports and supporting facilities, houses of worship, residential buildings, markets, and communications networks. Archaeological evidence and historical data reveal that Kema is known as a seaport that plays an important role in global trading during the Colonial period. Kema is even designated as one of the free ports in Sulawesi Sea. The role of Kema is currently declining, only as a fishing port no longer as an ocean port.
\end{abstract}

Keywords: Kema; Sulawesi sea trade; colonial period

\section{INTRODUCTION}

Kema is a subdistrict area in North Minahasa District that has been known as a seaport by foreign countries since $16^{\text {th }}$ century AD. Currently, Kema is a fishing village consisting of three villages, Kema Satu, Kema Dua, and Kema Tiga. According to Kumaat (1996), the Portuguese ship arrived at Kema in 1546 and its crew settled there. They then built fortresses, places of worship (churches), and prisons. Kema evolved into a port that many foreign merchant vessels (Kumaat, 1996: 37) visited. Kema was originated from the word of "kima" in Minahasa language, which means big shell, while the meaning of 'Kema' which came from the Spanish word, 'Quema' means flame, or also kindle. The notion was attributed to the actions of Spanish sailors that often making trouble by burning the area. Governor Robertus Padtbrugge in the memory of the handover of office on August 31, 1682 referred to this place as "Kemas of grote Oesterbergen," which means large mountains resembling large shells (Palar, 2009: 165).
Approaching the $17^{\text {th }}$ century, the Dutch had taken over Kema and organized it into a port city and a local government center (Tim Penelitian, 2012: 142). Kema evolved as a capital from Pakasaan Tonsea since the era of Xaverius Dotulong government. In his letter to the VOC governor in Ternate on February 3, 1770, revealed that his father, I Runtukahu Lumanauw lived in Kema and pioneering its development (Nayati, 2012: 9). In the 1800 s, the Kema port were more crowded than the Manado port, due to geographical conditions that Kema was safer harbor from ocean waves and the Philippines pirates. British and American ships regularly anchored in Kema to trade with local people (Schouten, 1998: 56).

Name of Kema was associated with the construction of a Spanish military base when Bartholome de Soisa landed in 1651 and established a port in La Quimas. The locals called it by maadon or kawuudan. The Spanish fortress was located at the estuary of the River Kema, as the Netherlands calles it Spanyaads gat or Spanish Burrow. Hendrik Berton in memory of August 3, 1767, described Kema, besides as a port for the West season, 
also the capital of Tonsea (Kawilarang, 2007). Kema's current condition is a densely populated fishing village. The life of the Kema community now blends in between the settlers and indigenous population, thus creating a harmonious pluralistic society. Archaeological remains consist of an old prison located in the middle of the settlement. Related to this matter, the problem to be discussed in this research is:

a. What are the archaeological evidences reflecting that Kema once became a bustling city in colonial times?

b. What is the role of Kema port in trade traffic in the Sulawesi Sea of $17^{\text {th }}-19^{\text {th }}$ century?

The purpose of this study is to recognize and prove the role of port (Bandar) Kema in Sulawesi Sea trade traffic in the $17-19^{\text {th }}$ century. This objective is closely related to Kema's current state, and the ignorance of Kema's community concerning their historical background.

\section{METHODS}

This study uses a historical archaeological approach that combines archaeological data with nonarchaeological data derived from the past. Historical archaeological study is an archaeological study that uses written sources in addition to the main source of artifacts

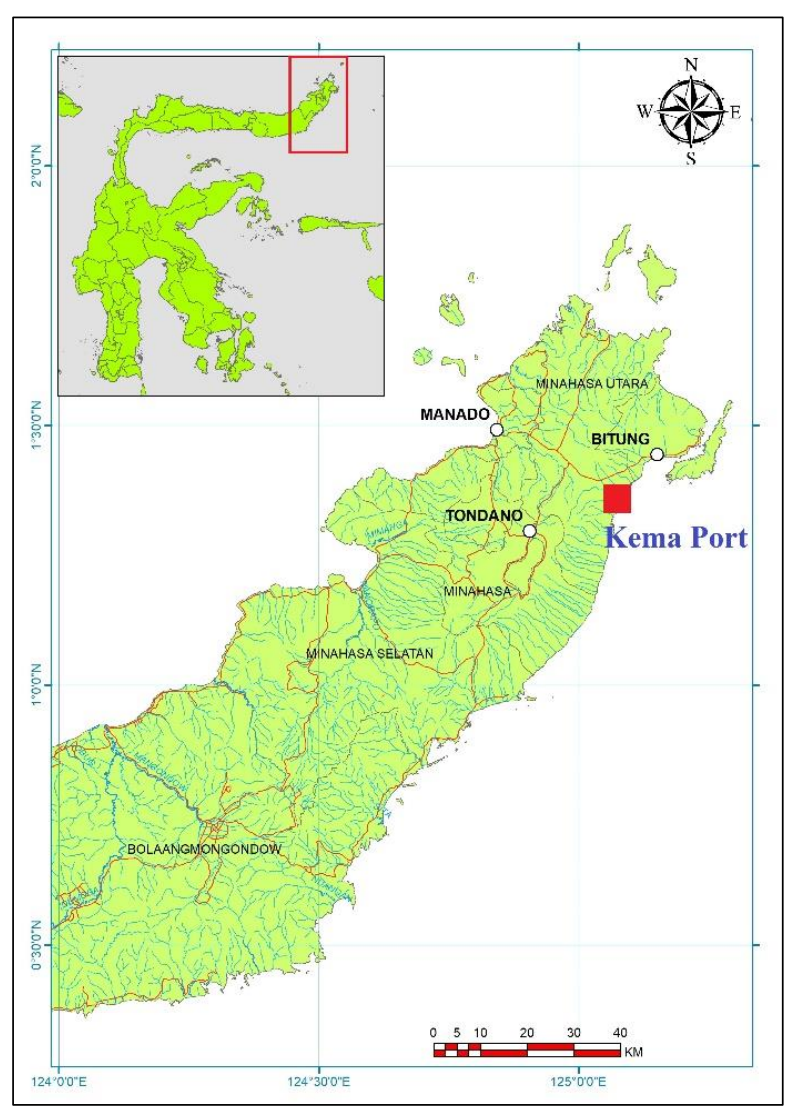

Figure 1. Map of Kema Port location

(Source: Basemap from Badan Informasi Geospasial, modified by Author, 2018)
(Spencer-Wood \& Baugher, 2010: 465). Historical archeology focuses on the study of archaeological remains and written records relating to the historical artifacts (Funari et al., 1999: 2).

In order to uncover the past lives, historical archeology studies cultural history and cultural processes using historical documents (Iriyanto, 2010: 26). The study of historical archeology is simply focused on the period of history (after the introduction of writing), and is defined as the study of material relics from various historical periods (Hall \& Silliman, 2006: 2; Orser Jr, 1996: 6). By using the data of writings or archives in addition to existing material data, historical archaeology is expected to reveal more historical archaeological remains in Kema.

The research sites are located in Kema Satu, Kema Dua and Kema Tiga areas, Kema District, North Minahasa District, North Sulawesi Province. The phase of research includes preparation, data collection, data analysis, and conclusion. Preparation phase consists of literature review and initial observation of the research object. Data collection includes collecting primary data in archaeological remains located in the research area, and secondary data includes old manuscripts, archives, drawings and photographs. The research data collection is conducted through several stages, literature study, archive study, field observation, and interview.

Following data collection, the next step is data analysis by identifying material and spatial analysis. Spatial analysis is conducted to figure out the functional relationship between buildings in one area, and the relation of environment around the site. Analysis is a process in obtaining correlation between various data gained from the observation.

\section{RESULT AND DISCUSSION}

\section{Kema Archaeological Evidences as a Port City (Bandar)}

Based on data in the field, there are archaeological remains indicating that Kema was an important port city (bandar) in the ancient times, including pattern of settlement and roads, prisons, ports and old warehouses, churches, tombs, old houses, communication facilities (underwater cable networks), and ceramics.

\section{Pattern of Settlements and Roads}

The pattern of Kema settlement is a grid bounded by road, organized and not following the traditional Minahasa settlement pattern. Kema settlement was originally a settlement of the Spanish who settled and refused to return to their homeland. They got married with indigenous women and live for generations (Marzuki, 2017: 37). The descendants of such mixed marriages in the Minahasa community are known as 
borgo. The word borgo comes from the term of vrijburgers which means free citizens (Wojowasito, 2000: 112). During the Dutch colonial period, the Borgo community was granted with special privileges, among others: released from corvee (rodi) labor, higher status from indigenous population, and allowed to use Dutch family name (Kristanto, 1996: 2). The Borgo people were also called as Inlandsche Burgers who were included in the army structure as schuterij, with the task of guarding and becoming troop reinforcements in the Dutch army structure (Parengkuan, 1983: 58).

In addition to the offspring of European and Minahasa marriages, those who belong to the borgo class are:

1. Mercenary army and shooters (schutterij) and their descendants.

2. Liberated slaves (mardijker) and employed as helpers in defense and security along with their descendants.

3. The Dutch (army and clerk) who were perverted and sentenced, and then released and remained in the colony.

4. Indigenous people who have sworn and are willing to be Dutch servants (workers) (Manoppo, 1977: 38).

In 1660, there were three settlements in Kema, namely Kema Pondol, Kema Letter A, and Kema Letter B. Each village was headed by a wijkmeester who also served as magistraat (prosecutor) (Kumaat, 1996: 37). Kema Letter $A$ was inhabited by borgo people, Letter $B$ included descendants of Moslemic immigrants, and Kema Pondol was populated by Minahasa natives. In the 1950s there was a change of government administration, Letter A was changed into Kema Dua Village, Letter B into Kema Tiga, and Kema Pondol to Kema Satu. The location of Kema Dua is flanked by Kema One in North and Kema Tiga in South (Tim Penelitian, 2012: 142). The atmosphere of Kema's life is similar to the life in which the Europeans live throughout the archipelago. The population of Kema in 1874 was 1,623 people, divided into three, which were borgo (Christian and Moslem) by 1,068 people, indigenous people (pribumi) 388 people, and the Dutch were 167 people (Graafland, 1991: 471).

The separation of settlements by ethnic is one of the hallmarks of the colonial city. The background of the separation of settlements was based on the Chinese rebellion in 1740. The rebellion resulted in the Chinese unallowed to live within the city walls and was obliged to stay in groups in a soldier-controlled area outside the city (Leushuis, 2014: 12). The rules also applied to other ethnic groups (Arabic, Indian, and indigenous). In order to corroborate it, in 1830 a legislation was issued which regulated ethnic division on colonial society and urban spatial plan (Leushuis, 2014: 14).

The condition of Kema settlements in the 1800s was described to be (Graafland, 1991: 471) well-groomed with beautiful gardens. There was a good loji for the controllers and major. In addition, there were nice homes for European residents. Europeans generally build houses by consideration of comfort, safety, health, and beauty and the ease of access and supervision (Nuralia, 2017: 2). Houses are made more magnificent with better materials than indigenous houses to reflect their higher social status (Nuralia, 2017: 15).

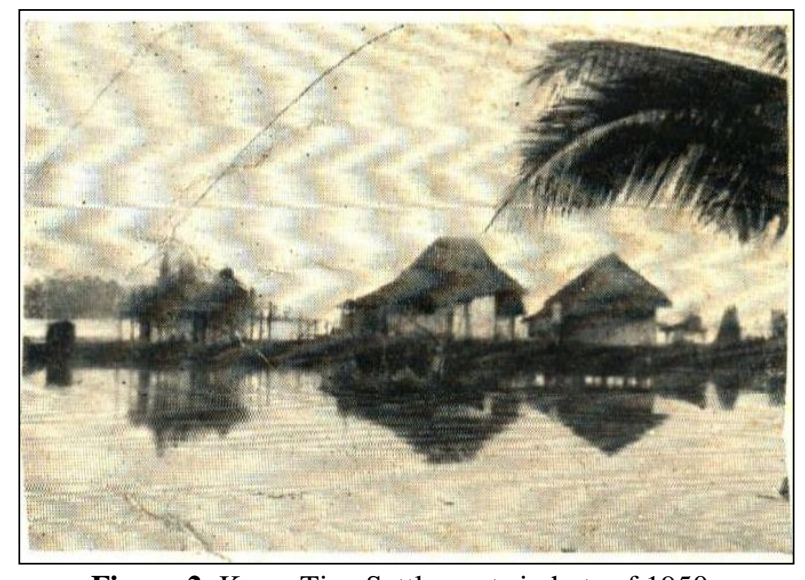

Figure 2. Kema Tiga Settlements in huts of 1950s (Source: Bhatta, 1958)

House of the borgo is stage house with a height between 2-3 m, with wood material and roof of rumbia. Beginning in the 1920s, the structure of the house was changed to a shorter one (Kumaat, 1996: 36). Borgo Kema society still uses the name of European clans, such as Van Ditch, Conelis, Koyansen, Elias, Andries and still holds the European tradition. One tradition that is still implemented is a rule concerning the use of outfit in the funeral. The mourners should wear white shirt, tie, full black suit along with loafers boots and sunglasses (interview with Markus Koyansen, and Cornelis Elias dated March 10, 2017). In addition to Borgo settlement, there were settlements of Muslim immigrants from Ternate, Gorontalo, Bugis, and Makasar. The immigrants initially only made small huts (daseng) to take shelter when stopped by from fishing, gradually became a settlement in Kema Tiga. Until the 1950s the conditions of Kema Tiga settlements were still simple lodges near the swamps and beaches (Bhatta, 1958) (Figure 2). The grouping of Kema Moslemic settlements differed from Moslemic settlements in Moslemic royal cities based on ethnic origin (Handoko, 2015: 36). The Moslemic Settlement in Kema is a settlement of various ethnicities (Makassar, Bugis, Ternate, Tidore, Gorontalo, Java, and Bolaang Mongondow) united in the same religious ties, namely Moslem. 
Minahasa traditional settlements in the past were generally located in the hills that were difficult to reach and far from the beach. The coastal area was not desirable for traditional Minahasa people because of:

a. Adverse climatic conditions (hot, humid, and swampy)

b. Sandy and less fertile soil

c. Unsafe due to attacks of the Mindanau and Tobelo pirates

d. Traditional Minahasa community was generally a farmer (Bhatta, 1958: 8).

e. Expansion of King of Bolaang Mongondow to Minahasa land which aimed to take over the fertile land, and required the Minahasa population to be employed as farmers and slaves for sale (Pangemanan, 2004: 43; Riedel, 1869: 511-512).

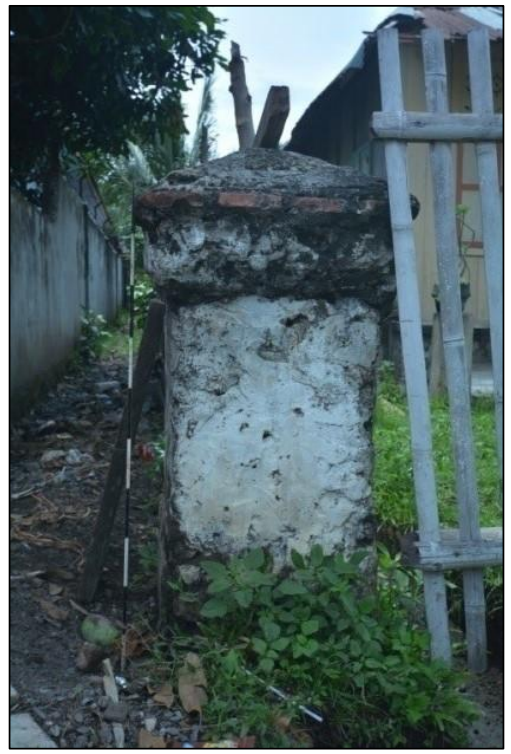

Figure 3. Pillar as boundary of Kema settlement area (Source: Balai Arkeologi Sulawesi Utara, 2017)

The pattern of traditional Minahasa settlement was clustered stretching along the road, consisting of several large houses, which can accommodate 5-20 families (Renwarin, 2007: 107-108). Traditional Minahasa house had the form of stage house with high pillars (Tim Penyusun, 1978: 111). Following the earthquake of 1845 the Minahasa settlements were moved to a level place, and the roads were arranged in order. The shape of the house was changed to a shorter and smaller size (one family for one house) with a knockdown wooden construction (Kojongian, 2006: 70; Parengkuan, 1983; Renwarin, 2007: 108; Tim Penyusun, 1978). The settlement layout also aims to optimize neatness and improve the health of its inhabitants (Henley, 2005: 311) and facilitate the control by colonial rulers (Taulu, 1955: 44). According to the Dutch government, the condition of traditional Minahasa settlements was considered less healthy. Large homes with many families and had little ventilation lead to various diseases (Henley, 2005: 311). Settlement area was bordered by pillars made of rock, mortars and plastered (Figure 3). According to H. Ismed Jailani (one of the elders of Kema Tiga), there are still many pillars around the house yard in the present, but it is more scarce.

Kema road network was divided into two, which were inter-district (region) road network and intradistrict (region) road network. The inter-district road network includes Kema-Manado road network, KemaAertembaga, and Kema-Watudambo. Kema-Manado road network is the main road in Minahasa since the $17^{\text {th }}$ century. The road conditions were relatively level; there was no extreme slope and downhill and there were no significant turns. This road network passed through a village where coconut plantations, rice fields, and farms were located. On the left and right edge of the road, there are walnut and nutmeg plants as a street shade.

Kema intercity road network in the 1800s was described to be well-groomed, clean and provided with posts. During the reign of Resident of Jansen (18521859), the arrangement of road network in Minahasa region was under the supervision ofF.W. Paepke Bülow, an expert land surveyor from the Department van Burgerlijke Openbare Werken (Watuseke, 1962: 44; Parengkuan, 1986: 31). In addition to supervise the construction of roads, Paepke Bülow also teaches the heads of Manado and Minahasa and his people on how to build up the roads. The road structure is reinforced with stone and pebbles on the top layer. Drainages and gutters are built on the side of the road in order to drain rainwater (Watuseke, 1962: 44).

The Kema-Manado road had a length of 20 miles ( \pm $32 \mathrm{~km}$ ), and there were 10 bridges with good construction (Allied Geographical Section, 1945: 45). The road condition was clean and was one of the best roads in Minahasa. The road traffic was crowded, and there was even an effort to build a railway network between Manado-Kema (Graafland, 1991: 475). This was confirmed by road map data of road construction plan issued in 1922, planned construction of railway between Manado-Kema, but it was not implemented.

Kema-Aertembaga and Kema-Watudambo road network was built between the 1930s and 1940s. The Kema-Aertembaga Road passed through three bridges made of iron and wood. Road conditions varied between flat, slightly uphill and uphill through the hills. This road network passed through coconut plantations, forests, and seashore. This road was built during the Japanese occupation of Minahasa (Allied Geographical Section 1948: 53).

The road network within the village had the grid and regular form (Figure 4). The village was divided into square blocks. There were inter-block roads connecting each other's settlements. The street at Kema in the 1800s 
was straight and had beautiful gardens. On the left and right side of the road there were shady fruit trees (Graafland, 1991: 470). According to Prof. Dr. Juddy Waani, M.T (interview dated March 7, 2017), grid road pattern of the era (the 1800s) was unknown in Minahasa traditional community. Road network pattern in Minahasa traditional community was still patterned in linear, following the topography of the region.

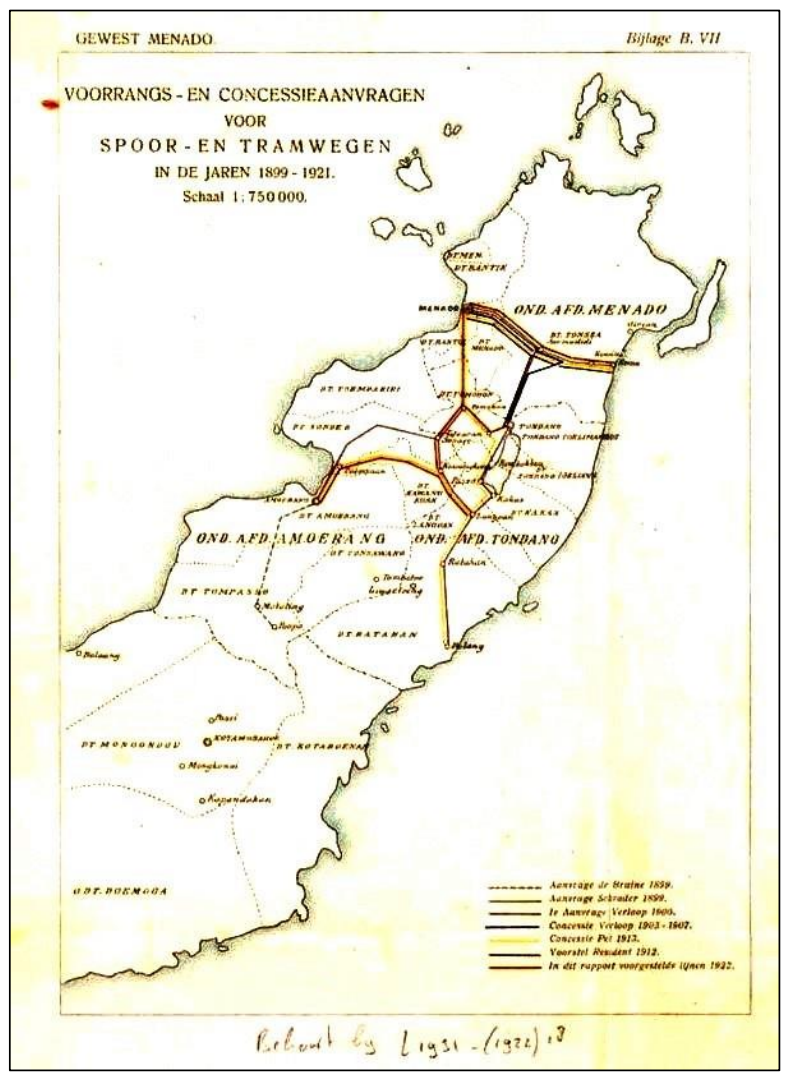

Figure 4. Minahasa road network pattern in 1922

(Source: www.leiden.edu.nl, retrieved December 20, 2017)

\section{Defense and Prison Buildings}

As described in the introduction above, that the Portuguese and the Spanish had built a fortress at Kema, however, the exact location of the fortress was yet unknown to this date. Fortress is a shelter or defensive building against enemy attacks (Mansyur, 2014: 85). The background of establishing a fortress was two, namely to protect strategic trade routes, and to support the colonial political goals (Marihandono, 2008: 158). The establishment of a fortress for the purpose of protecting trade routes usually lies in trade routes, such as coastal area, near harbors, and rivers. For colonial political purposes, it is usually located adjacent to the center of traditional government (the palace or the center of the kingdom).

The fortress plays an important role in the development of morphology and city spatial planning since some cities originated from fortresses that later developed into urban (Marihandono, 2008: 144), such as Fort Rotterdam (Makassar) and Nieuw Victoria
(Ambon) (Mansyur, 2014: 86). Over the times, the function of fort had changed. It is no longer a place of defense, but also as a place of government (Mansyur, 2014: 85; Marihandono, 2008: 145) and temporary storage of agricultural produce to be exported abroad (Hartono \& Handinoto, 2007: 91).

Based on the record (Molsbergen, 1928: 134) as cited by Palar (2009: 166), in 1778 there was a small fort in Kema built by the Dutch government called as "Utrecht." The fort was fortified by a force of 16 personnel, consisting of one sergeant, two corporals and 16 soldiers with one cannon and shooter (Sigarlaki, 1977: 64). Another source about the existence of the fort at Kema came from a photo of KITLV's collection that mentioned the Fort Kema in North Sulawesi (Figure 5). It is yet unknown whether the Fort Kema (Fort Te Kema) was a development of Portuguese, Spanish, Utrecht or new fortress in a different location. In 1851, the number of Dutch troops in Kema was 171 people consisting of one lieutenant, one sergeant major, 6 sergeants, one courier, 12 corporals, 2 drummers and 148 schuterij (shooter) (Algemeen Verslag in 1851 collection of National Archives of Republic Indonesia).

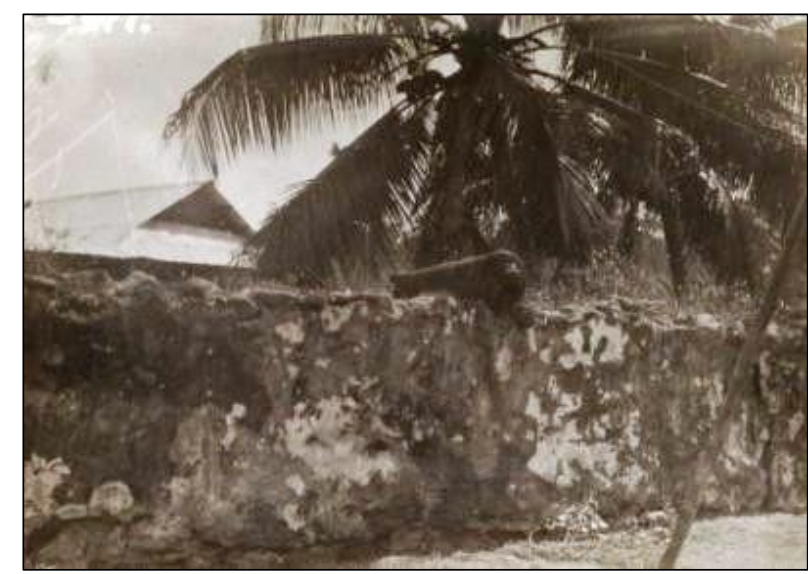

Figure 5. Fort Kema (Fort Te Kema)

(Source: www.kitlv.nl, retrieved December 20, 2017)

The background of construction of the fortress in Kema was to sustain economic interests, which was preventing illicit trade in the Sulawesi Sea region and inhibiting Mangindano (Mindanau) pirate attack (Kumaat, 1996: 64). The existence of the fortress in Kema is now no longer known, as the area of Kema has turned into a densely populated village. Based on a preliminary study conducted by the Balai Arkeologi Sulawesi Utara (North Sulawesi Archaeological Center) in 2017, there were findings of longitudinal wall structures with rock material presumably to be former fort structures (Marzuki, 2017: 30) (Figure 6). According to H. Ismed Jailani (64 years), in the 1970s there were still many remains of the wall in the middle of the settlement, but this time no longer exist. Some were demolished; others were connected with new buildings 
on the top layer. In addition to the fortress, there was a prison building located in Kema Dua Village, with coordinates $01^{\circ} 21^{\prime} 52.00^{\prime \prime}$ North latitude and $125^{\circ} 04^{\prime} 32.40^{\prime \prime}$ East longitude. Prison conditions are currently in the middle of densely populated settlements located $\pm 500 \mathrm{~m}$ from the beach. The prison building is made of composite stone layers plastered and chalked, measuring 9.20 meters in length, 7.50 meters in width, and 7.25 meters in height. It is now in a well-maintained state and has been recorded as a cultural heritage building with the register number of BPCB.GTO/71/06.01/ 0180/2014.

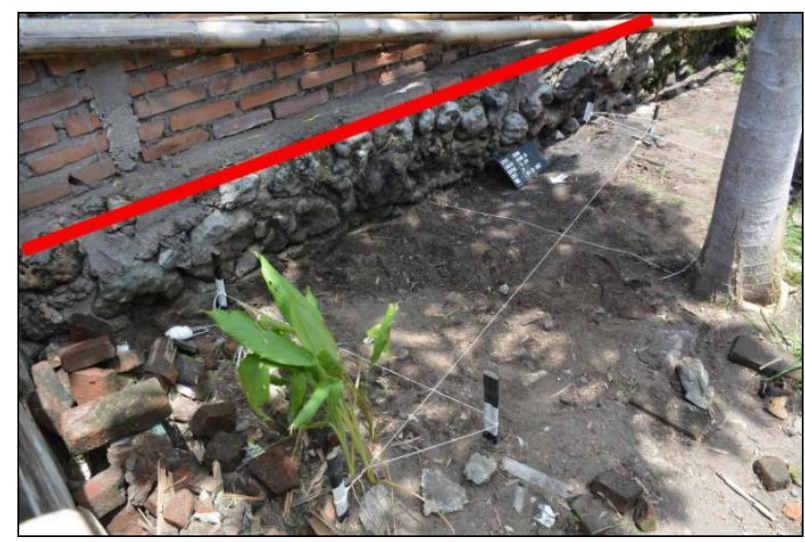

Figure 6. Wall structure estimated to be the fort (red line below)

(Source: Balai Arkeologi Sulawesi Utara, 2017)

\section{Port and Used Warehouse}

Kema Port was known by the local residents with the term of haven. Kema Port was originally a natural harbor located in Kema Bay near the estuary of the Kema River. According to Asnan (2009: 17), the natural harbor was a port that only utilized the "facilities" provided by nature, for example by simply utilizing a bay that has adequate depth and calmer water thus allowing the ship to dock. There were no human (artificial) additional facilities at this port. This type of port only serves as a large ship berth. The process of loading and unloading of goods was assisted by small boats. The Kema Port was used by the Resident Assistant in 1829. The ships performing activities at ports include paduakang boat, schoener (speedboat), panlarij, bolotto djulong-djulong, korrakorra, tjambereo, rohere, and galai (Hasanuddin \& Amin, 2012: 153). The description of the 1850s Kema port condition was a good port, even better than Manado, although it can only be used in the west wind season. A number of steamers, and whaling boats anchored to fill in food and water (Graafland, 1991: 471). In order to support the smoothness of loading and unloading activities at Kema port, the Dutch colonial government built two coal warehouses and a new dock replacing the old damaged one in 1858 (Administrative Verslag in 1858 collection of National Archives of the Republic of Indonesia).
The remaining archaeological artifact in the former port of Kema was the rest of warehouse building. The site of the former Kema port was located in Kema Tiga Village, Jaga 14, with coordinates of $1^{\circ} 21^{\prime} 35^{\prime \prime}$ North latitude and $125^{\circ} 04^{\prime} 21^{\prime \prime}$ East longitude. The rest of the warehouse foundation was located around the house of the Lausa family in the form of foundations that are no longer intact. Some parts have been destroyed, thus it required an effort to search by tracing the rest of existing foundations. Based on the search for the rest of the foundations, it is estimated to measure $40 \mathrm{~m}$ X $14.2 \mathrm{~m}$. In addition to the rest of the foundation of warehouse, other findings found in the Kema port in the present day is a block-shaped wooden pole in the middle of the sea which is presumably to be a former dock. The wood was visible when the sea water receded and will disappear when the tide is high (interview with Markus Koyansen dated March 10, 2017).

\section{House of Worship Building}

The house of worship building was a church in Kema Dua Village, with coordinates $1^{\circ} 29^{\prime} 13$ " North latitude and 124'50'18" East longitude. The church building was originally built by Portuguese in 1579 for the worship of the Catholic religion. The presence of the VOC in Minahasa in 1677 did not only monopolize trade, but also the monopoly of religious dissemination (Rompas, 1995:5 9). They forced Catholics in Minahasa to embrace Protestant Christianity (Mukhlis et al., 1995: 98) and forbade the spread of Catholicism (Rompas, 1995: 59). The condition also occurred in Kema that the Catholic Kema church turned into a Protestant Christian church. Aside from being a place of worship, the church also functions as a school in the past (Marzuki, 2017: 44). Currently, the building of Bait el Church has undergone a total change, thus the original form no longer exists. The church building was estimated to have been built on October 14, 1868. The remaining archaeological artifacts in the present day are church bells, communion tools, and former poles. Church bells are made of brass and read the writing of KEMA 1882 . It is no longer used and placed in a glass case (Figure 7).

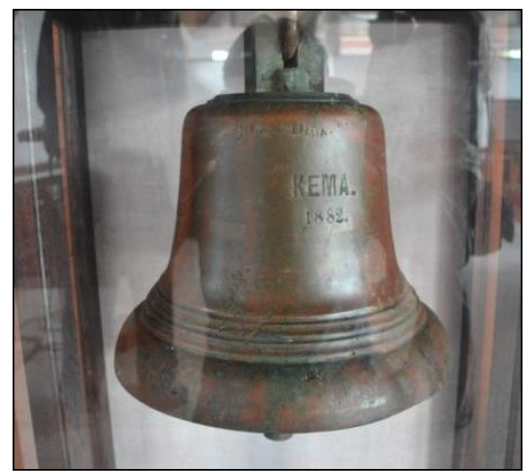

Figure 7. The bells of El Bait Church with the writings of KEMA 1882

(Source: Balai Arkeologi Sulawesi Utara, 2017) 
A set of communion tools consisting of teapots, cups, saucers, plates, and trophies are made of silver. At the moment these items are no longer used and kept as part of the church's history. The church had undergone a massive renovation and was inaugurated in 2002. The remaining old building materials are only the four main pillars which are now placed next to the church. In addition to the remains of the church, there is the foundation remains of the mosque in Kema Tiga built by H. Yahya from North Maluku, but it is unknown exactly when it was built (Tim Penelitian, 2012: 118). The mosque building was destroyed during a massive flood in 1936, and now only the foundation remains. Its location is near the Adiot Meidy family house, with coordinates of $01^{\circ} 21^{\prime} 78.8^{\prime \prime}$ North latitude and 12504'54.8" East longitude (Tim Penelitian, 2012: 118).

\section{Tomb}

Traditional Minahasan societies in the past have not known the burial grounds in particular, as the funeral for the deceased family was a stone grave (waruga) placed in the (front, side or back) courtyard. Land use for public cemeteries in Minahasa began in the 1820s after a cholera outbreak in Minahasa. The Dutch government banned the cemetery with waruga around the dwelling places and placed burials ground in a separate area outside the settlement. The ancient tomb remains in Kema Dua public cemetery with coordinates of $1^{\circ} 21^{\prime} 53^{\prime \prime}$ North latitude and $125^{\circ} 04^{\prime} 21^{\prime \prime}$ East longitude and a height of $13 \mathrm{~m}$ above sea level. The figures who were buried here including the kontrolir Haga and Christian missionary, Frans Hartig.

\section{Tomb of Kontrolir Haga}

Kontrolir (controleur) is the supervisor and ruler of onderafdeeling during the Dutch colonial government. Kontrolir Haga was killed by Hendrikus Zakarias, a borgo who refused the forced labor (heerendienst) in 1879. As a result of these events, no more Kema residents use Zakarias clan (farm) as their family name, but at this time the name Zakarias was immortalized for

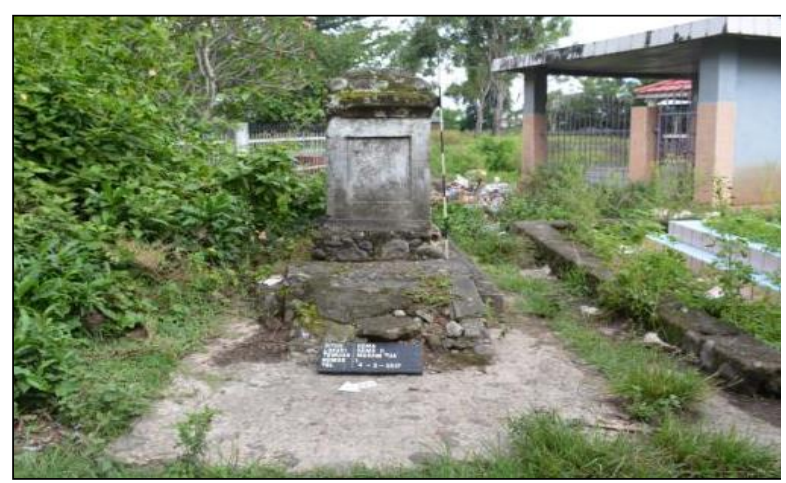

Figure 8. Tomb of Kontrolir Haga

(Source: Balai Arkeologi Sulawesi Utara, 2017) the street name in Kema Two. Condition of the tomb was not intact, box-shaped with a lot of decoration and ornaments that decorate the tomb building. The condition of the tomb is not well-maintained, located on the main roadside of the cemetery. The tomb is $150 \mathrm{~cm}$ in length, $110 \mathrm{~cm}$ in height, and $97 \mathrm{~cm}$ in width (Figure 8).

\section{Tomb of Franz Hartig}

Franz Hartig was a Christian proponent who came to Kema in 1848 (Watuseke, 1995: 18). The tomb was located in the middle of a public cemetery, the pyramidshaped head, the cube-shaped body, the footings or the bottom parts are not certainly visible as it is buried in the ground (Figure 9). The height of the tomb was measured by $94 \mathrm{~cm}$, body size by $83 \mathrm{~cm}$ x $85 \mathrm{~cm}$ and the head by $87 \mathrm{~cm} \times 89 \mathrm{~cm}$. In the pleated section located between the head and body, there was visible use of brick material. The material of the tomb uses grayish black cement. In the body part, there is a rectangular stone-shaped inscription.

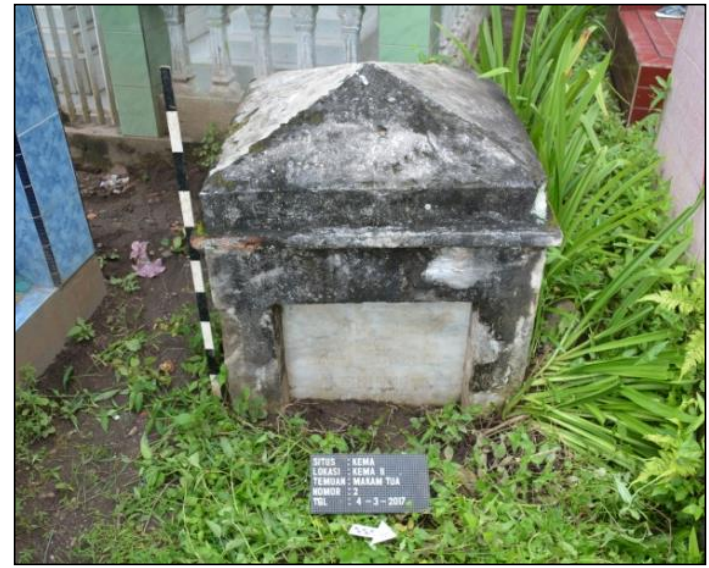

Figure 9. Franz Hartig's tomb at public cemetery in Kema Dua

(Source: Balai Arkeologi Sulawesi Utara, 2017)

\section{Old House}

There are some relics of old houses in Kema, including the office of Village Head (Hukum Tua) Kema Dua (Figure 10). Houses building was using stone and board or wood materials. Construction of houses use the concept of houses on stilts (stage house). The foot uses concrete material with the stairs in front part and there is a space below (kolong) that serves as the prison. The floor uses a tile with geometric and plain motifs (white, black, yellow, and red). According to the village head of Kema Dua, the building belonged to the Chinese in Manado, but then used as a school, and following the independence was used as a village office (interview dated March 10, 2017). The condition of the building is currently well maintained.

In addition to the old house that currently serves as the village head office, there is a Dutch controller (controleur) house building (loji) when Kema becomes 
the capital of onderafdeeling Kema. The building has now been moved to Tountaleted Village with coordinates of $01^{\circ} 23^{\prime} 08^{\prime \prime}$ North latitude and 1250 03' 21" East Longitude, and a height of $96 \mathrm{~m}$ above sea level (Figure 11). According to Markus Koyansen (59 years, interview on March 10, 2017), the building was originally located in Kema, but has long since been moved to Tountalete. The current building owner is the Nicholas-Tompunu family.

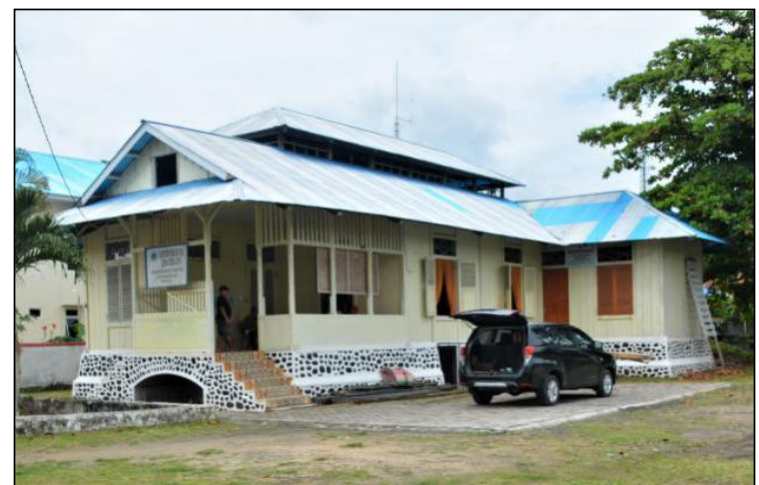

Figure 10. Old house is now functioned as the village head office

(Source: Balai Arkeologi Sulawesi Utara, 2017)

Loji building in stage house was measuring by $20 \mathrm{mx} 10 \mathrm{~m}$, and supported by 28 poles measuring $30 \mathrm{~cm} \times 30 \mathrm{~cm}$ with a height of $2 \mathrm{~m}$. Current conditions are already damaged, untreated, and no longer functioned. According to information, in 1998 the loji building was still in good condition and used as a residence of Governor Worang's relatives. At the top of the ceiling includes a fairly large room. In order to reach the upper room there are wooden stairs connecting to the main room.

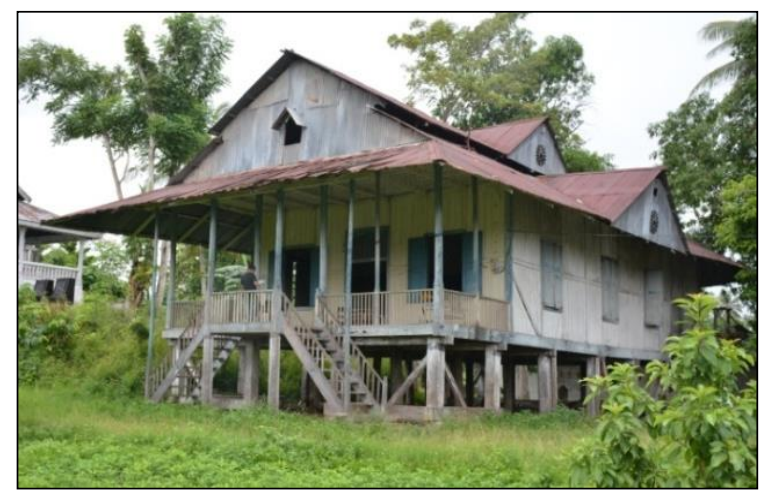

Figure 11. Kema Loji Building in Tontalete Village (Source: Balai Arkeologi Sulawesi Utara, 2017)

\section{Market}

Kema Market is one of the oldest markets in Minahasa. Until 1825 there were only three markets in Minahasa, namely Manado, Kema and Tondano, but not all markets had used the money as a means of exchange. Only Manado and Kema were already using money as a medium of exchange, while Tondano still used barter system (Watuseke, 1962: 43). Unlike other regions, intermediary traders in Minahasa did not come from Chinese. The Dutch government made a policy by banning Chinese merchants from becoming intermediary traders. The Dutch government established that intermediary traders should come from borgo, but it did not last long as the borgo people did not like trading, they chose to be farmers, fishermen, or soldiers (Kumaat, 1996: 67).

Based on community information, in the Kema region there has been a market since the beginning. The market location was now a new market, an old market in contemporary with the Colonial government was located in Kema Satu Village. The market location is now an empty garden located in a corridor on the side of the road of Kema-Kauditan (behind the Samaria Store) with the coordinates of $01^{\circ} 22^{\prime} 17,2^{\prime \prime}$ North Latitude and $125^{\circ} 04^{\prime} 16,7^{\prime \prime}$ East Longitude.

\section{Cable Site}

It is a submarine communication cable connecting Kema with Ternate and Ambon during the Dutch colonial period. It is administratively located in Kema Satu Village with coordinates of $01^{\circ} 22^{\prime} 0.4$ " North Latitude and $125^{\circ} 04^{\prime} 43^{\prime \prime}$ East Latitude. The location of the cable site is on the edge of Firdaus Beach which is the place of tourism in Kema Satu Village (Figure 12).

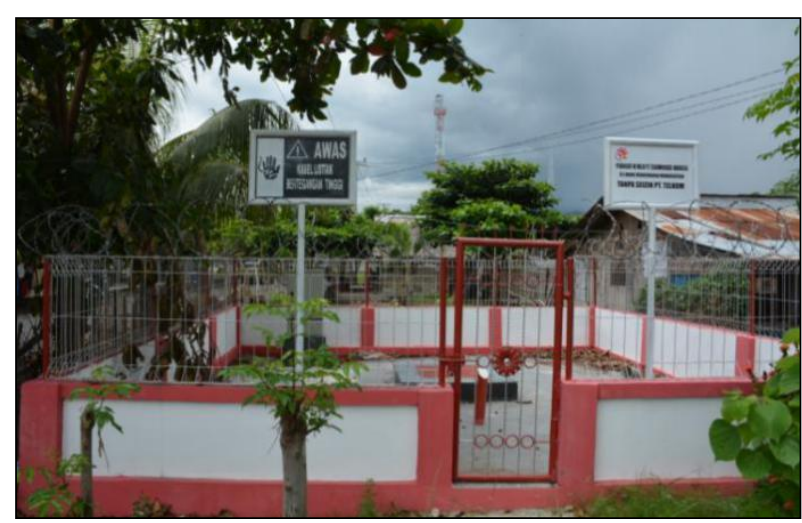

Figure 12. Cable site location

(Source: Balai Arkeologi Sulawesi Utara, 2017)

\section{The Role of Kema Port in Sulawesi Sea Trade}

Kema initially as a shelter and took up the freshwater supply of European ships was then developed into a security post and borgo settlement to become a port city that plays an important role in Sulawesi Marine trade traffic. According to Murphey as quoted by Sulistiyono, in the context of maritime history, there are two concepts about ports, such as harbour and port (Sulistiyono, 1994: 11). Harbour refers more to the physical concept, which is the port that serves as a berth or shelter for the ship. While the port refers to economical concept, it does not only regard the port as a berth or shelter, but also functions as a place to trade and exchange trade 
commodities between the countryside (hinterland) and the opposite area (foreland) (Murphey, 1989: 231-232).

Besides having an economic meaning, ports also have cultural, political, and geographical significance (Bintarto, 1968: 33). The economic meaning is related to the function of the port as the center of shipping and import-export activities and other related economic activities. Shipping and maritime trade are among variables that determine an indication of whether or not a port (Indriyanto, 2015: 36-37) is functioning. In terms of geographical, management, and commercial, it is related to the port function which includes ship activities from entering the port, loading and unloading, until leaving the port with the aim of expediting port service (Lawalata, 1981: 22-23). Port infrastructure in the form of docks, warehouses, and access roads also influence the development of ports from time to time. According to Sudjana (1996), a port must have at least three basic criteria that must take place and continue, namely: the correlation between the world or domestic market that allows correlation between the port with the inland areas associated with the outflow of goods, the formed transportation lines, merchandise collection centers in certain places, as well as correlation between port activities with the establishment of a port city, i.e. the port can attract labor and give a certain life tones to the port city community (Sudjana,1996: 177).

Development and destruction of the port city is influenced by regional and international trade, the control over labor and the yield of the land, and the legitimation of princely power (Sulistiyono, 1994: 17). The coastal cities grew and developed from scratch with the same function, that is, as access to the connection between the inland and the outside world. Main characteristic of the coastal city begins as a settlement or post that grows on sheltered beaches located around the estuary, susceptible to flooded puddles, ship berths, and road network connecting to the inland area (Hantoro, 2002: 1). The condition occurred in Kema which started from the security post, then developed into a settlement around the river estuary, port city, and governmental center. Selection of Kema's location as one of the ports during colonial period was due to its location adjacent to the river estuary and the ease of obtaining fresh water sources. The area around the estuary is a strategic location for the port (Lapian, 2009: 95). The ease of fresh water is obtained by taking Kema River water. According to H. Ismed Jailani, in the 1970s the water condition of the Kema River was still very clear, as the stones on the river bed were clearly visible and the surrounding community mostly uses it for daily life. The current condition of river water is brownish due to quarry mining in upstream part of the river. In order to accelerate the flow of goods traffic to Manado and Minahasa hinterland, a road network was built by the
Dutch government. The Kema-Manado road network was built by the Minahasa community before 1850 , expanded during the forced cultivation of coffee in 1850 (Limadharma, 1987: 68).

The growth and development of coastal cities was largely determined by the city's ability to perform its functions as a seaport (Nurhadi, 1996: 3). Furthermore, it is explained that the requirement of coastal city location to develop seaport infrastructure are two, they are: (a) feasibility of infrastructure for big boat (ship) to harbor, i.e. a dock which the ship can anchor, and means of warehousing; (b) must have productive hinterland areas in global trade activities (availability of exportable quantities of merchandise) (Nurhadi, 1996: 3). Since the 1800s, the Kema port has included in the commercial voyage of the Dutch shipping line, starting with Cores de Vries, NISM and KPM (Figure 13-18). The main commodities exported from Minahasa in the 1800 s were rice, copra, chocolate, coffee, and cloves (Kartodirdjo, 1973: CXVII; Makkelo \& Budiman, 2010: 40; Mawikere, 1997: 65; Schouten, 1998: 53-54; Taylor, 2003: 270). Manado Coffee was incredibly famous in the Netherlands. "Manado is a good brand" was stated by Batavus Droogstoppel, a coffee trader at Lauriergracht, Amsterdam in the novel of Max Havelaar (Schouten, 1998: 53).

The development of Kema port increased with the increasing status of Kema port into a free port in 1888 (Schouten, 1998: 60) which aimed at centralizing the trade activities of the indigenous population to the port, as well as preventing trade and political relations with other European nations (Poelinggomang, 2002: 79). Development of Kema port was supported by development of port facilities and infrastructure such as docks, warehouses and road network. Based on Administrative Verslag report in 1858 (ANRI collection), in order to facilitate loading and unloading of goods, a new dock was built at Kema and Manado ports.

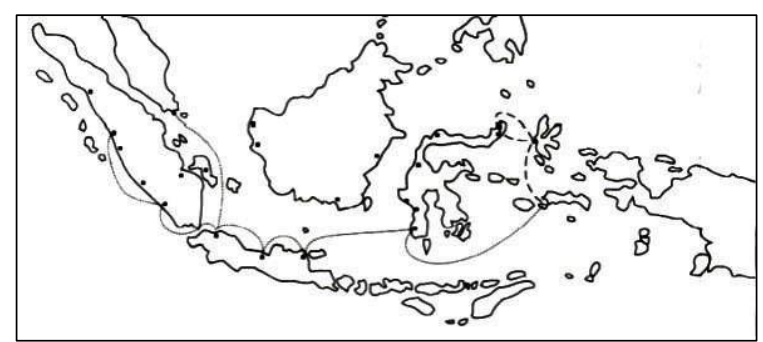

Figure 13. Cores de Vries shipping line 1850-1859

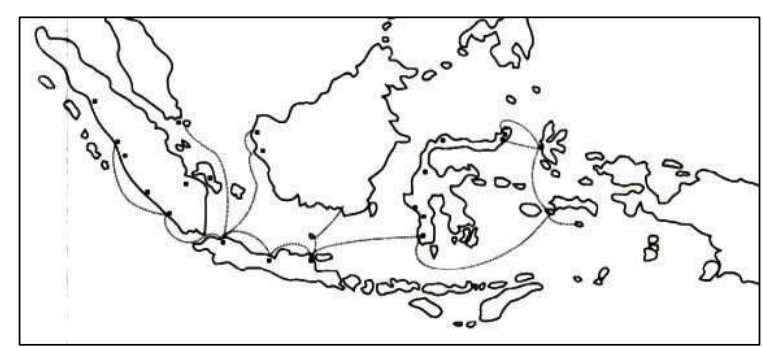

Figure 14. Cores de Vries shipping line 1860-1865 


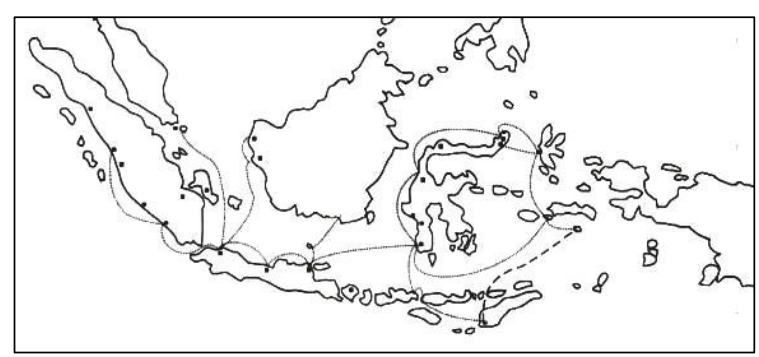

Figure 15. NISM shipping line 1866-1875

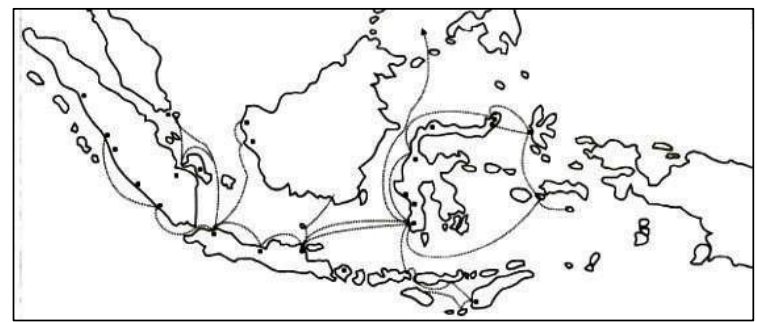

Figure 16. NISM shipping line 1875-1890

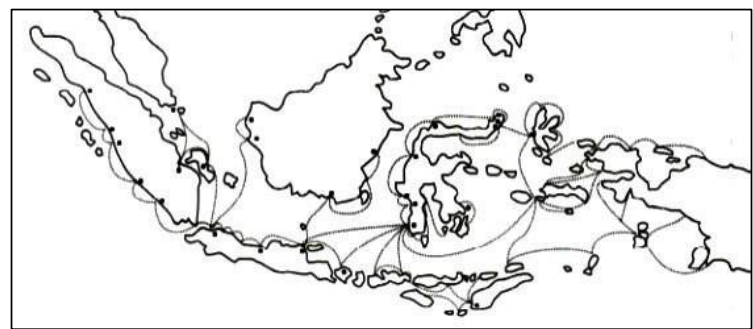

Figure 17. KPM shipping line 1891-1894

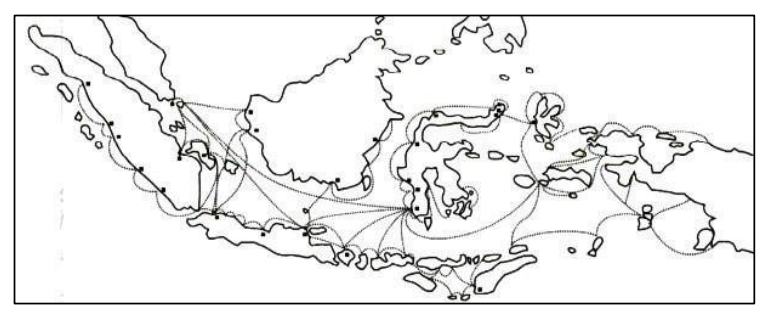

Figure 18. KPM shipping line 1895

Kema was not just evolved to be a seaport, but became one of the trading centers in Minahasa. Trading in Kema did not only involve local traders, but also foreign traders from outside the island. Kema was one of the areas that had a market in Minahasa in the 1800s, and had already used a currency exchange. Another market (Tondano) still used barter system (Watuseke, 1962: 43). The use of currency as a means of exchange proves that trade was not only done locally, but already global trade with the overseas. Another proof was the discovery of many ceramics from Europe found in the Kema beach. One of them was the ceramic collection of $\mathrm{H}$. Ismed Jailani that depicted the European army (Figure 19).

In the $20^{\text {th }}$ century, the port of Kema still plays an important role in trade traffic in the Sulawesi Sea. The commodity exported outside Minahasa in addition to coffee was copra. The coffee plants were produced from the mountainous area around Lake Tondano (Remboken, Eris, and Kakas), while copra was produced in most coastal areas of Minahasa. The coconut plants were only introduced the late $19^{\text {th }}$ century, but they have become a new belle in Minahasa region in 1920s (Wahyono, 1996: 4). This was because the copra trade was not monopolized like coffee. Although Minahasa coffee (Manado) was famous in the Netherlands and had a high selling price, at the farmer level, the price was incredibly low. This condition was due to the monopoly of coffee trade conducted by MHV (Moluksche Handel Venootschaap) (Sondakh \& Sembel, 1995: 49).

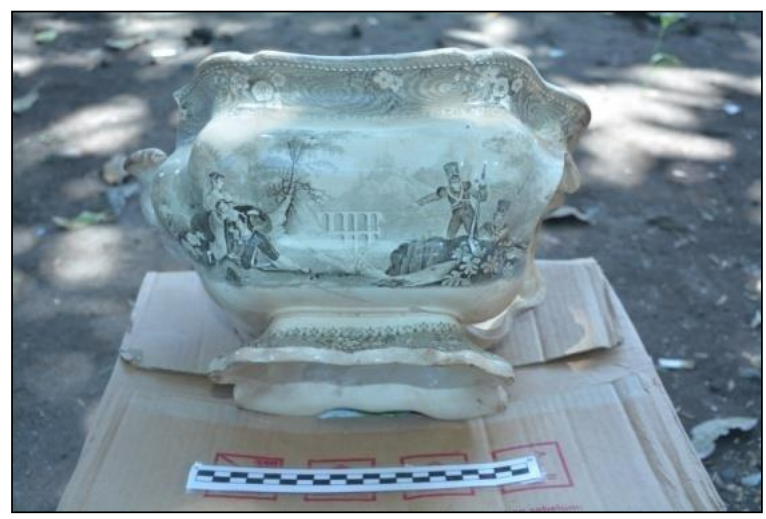

Figure 19. European Ceramics collection of H. Ismed Jailani

(Source: Balai Arkeologi Sulawesi Utara, 2017)

The first exports of Minahasa copra in the 1890s was 6,000 tons sharply increased to 27,298 tons in 1910 (Wahyono, 1996: 63). The rise and fall of ports in Minahasa (Manado, Kema, and Amurang) were affected by fluctuations in copra trade. The copra exports from Minahasa were increasingly affecting the import of other goods to Minahasa. When copra prices were higher, trading volume in Minahasa also increased (Wahyono, 1996: 20). The world's copra demand increased as coconut oil was found to be raw material of margarine and soap. These conditions affected the increasing role of Kema port as one of the entrances and exits of goods to the Minahasa.

In the early $20^{\text {th }}$ century, the Dutch colonial government made a policy of increasing attention to ports outside Java by improving facilities and management (Pradjoko \& Utomo, 2013: 327). Improvement of facilities at Kema harbor was an upgrading and development of road connecting Kema with Manado and other buffer zones (Tonsea and Tondano). The development of Kema harbor was influenced by the colonial government policy that developed the eastern archipelago trade traffic (Mulya, 2014: 13). Another policy that encouraged development of Kema port was the granting of primary rights to KPM (Koninklijk Paketvaart Matschapaij) in 1891-1906 to expand the commercial shipping network. Through this policy, the Dutch colonial government managed to reach the production areas in order to expand its communications and trade network with other regions (Nur et al., 2016: 621). 
The Port of Kema suffered a setback with the opening of a new port in Bitung since the 1950s. According to Murphey (1989) as cited by Indriyanto (2015: 3), the development of the port was strongly influenced by the hinterland and its connection with the opposite region represented by the ships coming to the port. For buffer zones, ports had function to attract ships from across the region in marine trade over buffer zone products. Factors causing the opening of new ports in Bitung to replace the Kema port included among others: Bitung waters conditions were calmer as protected by Lembeh Island in front part, and Bitung beach with deeper surface conditions making it easier for large boats to harbor, and Bitung geographic conditions which has a wider flat area that making it easier to build other port supporting facilities (warehousing and road networks).

Apart from being a port city (bandar), Kema evolved as a city center of local and colonial administration. Kema has been the capital of Pakasaan Tonsea since the 1700s (Palar, 2009: 165). Based on the map of Minahasa region in 1895, Kema became the capital of Kema afdeeling with the areas covering Tonsea and Maumbi districts. Kema underwent changes in line with the change of colonial rule in Minahasa. Afdeeling Tonsea with the capital of Kema were combined with afdeeling Manado in 1898 (Parengkuan, 1983: 38). In addition to the displacement of ports and government centers, the declining Kema was influenced by geographical factors of the Kema region which had only a few flat areas. The area of Kema was a mixed of swampy territory (Kema Tiga), slightly flat and hilly (Kema Dua), as well as wavy (Kema Satu). These conditions require greater costs and labors for development of a wider area than the Bitung region.

\section{CONCLUSION}

Based on historical data and archaeological evidence, Kema is one of the busier harbors and plays a role in Sulawesi Marine trade since the 16th century AD Archaeological evidence of Kema as a crowded port city (Bandar) which plays an important role in global trade in the Sulawesi Sea, among others, ports, warehousing facilities, settlement configuration, roads, defense buildings, prisons, houses of worship, old houses buildings, markets, and means of communication. Settlement configuration and road network in Kema was a modern pattern unknown to traditional Minahasa community at that time.

The Dutch colonial government considered the existence of the Kema port in Sulawesi's marine trade network to have an important position, thus establishing the Kema port as one of the free ports in 1888. Such declaration made the Kema port crowded with ships trading directly abroad. Kema Port was not only a transit port, but it has become an exporting port of Minahasa commodities directly (coffee, copra, rice, chocolate, and cloves) to overseas.

The declining existence of Bandar Kema was influenced by three things, they were the colonial government's policy to remove central government, geographical condition of Kema which only slightly have flat areas, and the opening of new port in Bitung.

\section{ACKNOWLEDGEMENT}

This article is part of a dissertation on the Development of Spatial and Urban Coastal Structure of Minahasa Inland in 1789-1945. My gratitude goes to Dr. Anggraeni, M.A. and Dr. Sri Margana, M.Phil., which has provided input in the writing of this article, as well as the North Sulawesi Archaeological Center which has included the authors in the research of Minahasa Coastal Cities in 2017.

$* * * * *$

\section{REFERENCES}

ANRI. (1858). Administratief Verslag van 1858. Jakarta: Arsip Nasional Republik Indonesia.

ANRI. (1921). Algemeen Verslag over de Residentie Manado 1800-1900. Jakarta: Arsip Nasional Republik Indonesia.

Allied Geographical Section. (1945). Makassar: SW Celebes. [s.l.]: Allied Geographical Section, Southwest Pacific Area.

Asnan, G. (2009). Pelabuhan-Pelabuhan Kota Padang Tempo Doeloe. Amoghapasa, 13/TahunXV, 17-20.

Bhatta, M. J. (1958). Tinjauan Tentang Kediaman Orang Jang Beragama Islam di Minahasa. Publikasi No. 8.

Bintarto, R. (1968). Beberapa Aspek Geografi. Yogyakarta: Penerbit Karya.

Funari, P. P. A., Jones, S., \& Hall, M. (1999). Introduction: Archaeology in History. In P. Funari, S. Jones, M. Hall (Eds.), Historical Archaeology (pp. 1-20). London: Routledge.

Graafland, N. (1991). Minahasa Negeri, Rakyat dan Budayanya. In L. R. Montolalu (Ed.) Jakarta: PT. Pustaka Utama Grafiti.

Hall, M., \& Silliman, S. W. (2006). Introduction: Archaeology of the Modern World. In M. Hall (Ed.), Historical Archaeology. Oxford: Blackwell Publishing.

Handoko, W. (2015). Tata Kota Islam Ternate: Tinjauan Morfologi dan Kosmologi. Kapata Arkeologi, 11(2), 123-138.

Hantoro, W. S. (2002). Pengaruh Karakteristik Laut dan Pantai terhadap Perkembangan Kawasan Kota Pantai. Bandung: Pusat Penelitian Geoteknologi LIPI.

Hartono, S., \& Handinoto, H. (2007). Surabaya Kota Pelabuhan (Surabaya Port City) Studi tentang perkembangan bentuk dan struktur sebuah kota pelabuhan ditinjau dari perkembangan transportasi akibat situasi politik dan ekonomi dari abad 13 sampai awal abad 21. DIMENSI (Journal of Architecture and Built Environment), 35(1), 88-99.

Hasanuddin \& Amin, B. (2012). Gorontalo dalam Dinamika Sejarah Masa Kolonial. Yogyakarta: Penerbit Ombak. 
Henley, D. (2005). Fertility Food and Fever Population, Economy, and Environmet in North and Central Sulawesi, 1600-1930. Leiden: KITLV Press.

Indriyanto. (2015). Menjadi Pusat Pelayaran dan Perdagangan Interregional: Pelabuhan Surabaya 1900 1940. Thesis Universitas Gadjah Mada.

Iriyanto, N. (2010). Benteng-benteng Kolonial Eropa di Pulau Ternate dalam Peta Pelayaran dan Perdagangan Maluku Utara. Thesis Universitas Gadjah Mada.

Kartodirdjo, S. (1973). Ikhtisar Keadaan Politik Hindia Belanda Tahun 1839-1848. Jakarta: Arsip Nasional Republik Indonesia.

Kawilarang, H. (2007). Dari Quimas menjadi Kema. Retrieved December 15, 2017, from http://www.theminahasa.net/

Kojongian, A. (2006). Tomohon Kotaku. Tomohon: Dinas Pendidikan dan Kebudayaan.

Kristanto, B. (1996). Sejarah Masyarakat Borgo di Tanawangko Minahasa 1919-1945. Thesis Universitas Sam Ratulangi.

Kumaat, N. A. (1996). Sejarah Masyarakat Borgo di Kema, Kauditan 1919-1945. Thesis Universitas Sam Ratulangi.

Lapian, A. (2009). Orang Laut Bajak Laut Raja Laut Sejarah Kawasan Laut Sulawesi Abad XIX. Jakarta: Komunitas Bambu.

Lawalata, H. A. (1981). Pelabuhan dan Niaga Pelayaran (Port Operation). Jakarta: Aksara Baru.

Leushuis, E. (2014). Panduan Jelajah Kota-Kota Pusaka di Indonesia. Yogyakarta: Penerbit Ombak.

Limadharma, H. K. (1987). Tanam Paksa Kopi dan Monetisasi Petani Minahasa, 1822-1870. Thesis Universitas Indonesia.

Makkelo, I. D., \& Budiman, M. (2010). Kota Seribu Gereja Dinamika Keagamaan dan Penggunaan Ruang di Kota Manado. Yogyakarta: Penerbit Ombak.

Manoppo, G. (1977). Struktur Bahasa Melayu Manado. Manado: Universitas Sam Ratulangi.

Mansyur, S. (2014). Sistem Perbentengan dalam Jaringan Niaga Cengkih Masa Kolonial di Maluku. Kapata Arkeologi, 10(2), 85-98.

Marihandono, D. (2008). Perubahan peran dan fungsi benteng dalam tata ruang kota. Wacana, 10(1), 144-160.

Marzuki, I. W. (2017). Laporan Penelitian Tata Kota Pantai Minahasa. Manado: Balai Arkeologi Sulawesi Utara.

Mawikere, F. (1997). Sekutu dalam Seteru: Gerakan Protes Kristen Minahasa dan Latar Belakang Politik Kolonial Etis Abad XIX sampai Awal Abad XX. Thesis Universitas Gadjah Mada.

Molsbergen, E. G. (1928). Geschiedenis van de Minahasa tot 1829. Weltevreden: Landsdrukkerij.

Mukhlis, P., Poelinggomang, E., Kallo, A. M., Sulistyo, B., Thosibo, A., \& Maryam, A. (1995). Sejarah Kebudayaan Sulawesi. Jakarta: Departemen Pendidikan dan Kebudayaan.

Mulya, L. (2014). Kebijakan Maritim di Hindia Belanda: Langkah Komersil Pemerintah Kolonial. Mozaik, 7(1), $1-18$.

Murphey, R. (1989). On Evolution of the Port City. In F. Broeze (Ed.), Brides of the Sea: Port Cities of Asia from 16th - 20th Century. Kinsington: New South Wales University Press.

Nayati, W. (2012). Mengenal Sulawesi Utara dari Sejarah dan temuan Arkeologis untuk Pembangunan Karakter dan Penguatan Jatidiri Bangsa. Yogyakarta: Mentari Pustaka.

Nur, N., Purwanto, B., \& Suryo, D. (2016) Perdagangan dan Ekonomi di Sulawesi Selatan pada tahun 1900-an sampai dengan 1930-an. Jurnal Ilmu Budaya, 4(1), 617-712.

Nuralia, L. (2017). Struktur Sosial pada Rumah Pejabat Tinggi Perkebunan Zaman Hindia Belanda di Jawa Bagian Barat. Kapata Arkeologi, 13(1), 1-20.
Nurhadi, (1996). Pantai Utara Jawa, Mobilitas Manusia dan Dinamika Perubahan Budaya Studi Kasus Akhir Masa Kolonial Abad 19-20 M. Jurnal Penelitian Arkeologi, 4, 3-9.

Orser Jr, C. E. (1996). A Historical Archaeology of the Modern World. Boston: Springer Science.

Palar, H. B. (2009). Wajah Lama Minahasa. Bogor: Yayasan Gibon.

Pangemanan, H. H. (2004). Politik dan Perubahan Masyarakat di Bolaang Mongondow 1895-1942. Thesis Universitas Gadjah Mada.

Parengkuan, F. E.W. (1983). Sejarah Sosial Sulawesi Utara. Manado: Fakultas Sastra Universitas Sam Ratulangi.

Parengkuan, F. E. W. (1986). Sejarah Kota Manado, 1945 1979. Jakarta: Departemen Pendidikan dan Kebudayaan.

Poelinggomang, E. L. (2002). Makassar Abad XIX: Studi tentang Kebijakan Maritim. Jakarta: Kepustakaan Populer Gramedia.

Pradjoko, D., \& Utomo, B. B. (2013). Atlas PelabuhanPelabuhan Bersejarah di Indonesia. Jakarta: Direktorat Jenderal Kebudayaan, Kementerian Pendidikan dan Kebudayaan.

Renwarin, P. R. (2007). Matuari wo Tonaas: Dinamika Budaya Tombulu di Minahasa. Jakarta: Cahaya Pineleng.

Riedel, J. (1869). Het Oppergezag der Vorsten van Bolaang over de Minahasa. In Bijdragen tot de Taal-, Land-en Volkenkunde van Nederlandsche-Indië, 17, 505-524.

Rompas, J. (1995). Pendidikan dan Perubahan Sosial Masyarakat Pedesaan di Minahasa. Antropologi Indonesia, 0(51), 57-63.

Schouten, M. (1998). Leadership and Social Mobility in A Southeast Asian Society Minahasa 1677-1983. Leiden: KITLV Press.

Sigarlaki, D. (1977). Sejarah Daerah Sulawesi Utara. Jakarta: PPSDB Departemen Pendidikan dan Kebudayaan.

Sondakh, L., \& Sembel, D. (2014). Pengaruh Ekonomi Pasar pada Teknologi Pertanian di Minahasa. Antropologi Indonesia, 0(51), 45-56.

Spencer-Wood, S. M., \& Baugher, S. (2010). Introduction to the Historical Archaeology of Powered Cultural Landscapes. International Journal of Historical Archaeology, 14(4), 463-474.

Sudjana, T. (1996). Pelabuhan Cirebon Dahulu dan Sekarang. In S. Zuhdi. (Ed.), Cirebon Sebagai Bandar Jalur Sutera. Jakarta: Departemen Pendidikan dan Kebudayaan RI.

Sulistiyono, S. T. (1994). Perkembangan Pelabuhan Cirebon dan Pengaruhnya Terhadap Kehidupan Sosial Ekonomi Masyarakat Kota Cirebon 1859-1930. Thesis Universitas Gadjah Mada.

Taulu, H. (1955). Sedjarah Minahasa. Manado: Badan Penerbit dan Penjiar Buku Membangun.

Taylor, J. G. (2003). Indonesia Peoples and Histories. New Heaven: Yale University Press.

Tim Penelitian. (2012). Laporan Penelitian Pusat Peradaban Minahasa Perkembangan Hunian dan Budaya Minahasa. Manado: Balai Arkeologi Manado.

Tim Penyusun. (1978). Adat Istiadat Daerah Sulawesi Utara. Jakarta: Proyek Penelitian dan Pencatatan Kebudayaan Daerah Departemen Pendidikan dan Kebudayaan.

Wahyono, E. (1996). Pembudidayaan dan Perdagangan Kopra di Minahasa (1870-1942). Thesis Universitas Indonesia.

Watuseke, F.S. (1962). Sedjarah Minahasa. Manado: Pertjetakan Negara.

Watuseke, F. (1995). Sejarah Perkabaran Injil di Minahasa, 1831-1942. Antropologi Indonesia, 0(51), 15-34.

Wojowasito. (2000). Kamus Besar Bahasa Indonesia. Jakarta: Balai Pustaka. 